\title{
A new squat lobster of the genus Munidopsis (Crustacea: Decapoda: Munidopsidae) from the Mediterranean Sea
}

\author{
ENRIQUE MACPHERSON \\ Centro de Estudios Avanzados de Blanes (CEAB-CSIC), Carr. Acc. Cala San Francesc 14, 17300 Blanes, Girona, Spain. \\ E-mail: macpherson@ceab.csic.es
}

\begin{abstract}
SUMMARY: A new species of Munidopsis Whiteaves, 1874 is reported from the south of Crete, at 2046-2104 m, in the eastern Mediterranean Sea. The species (M. ariadne) is morphologically closely related to M. maunga Schnabel and Bruce, 2006, from New Zealand. The species is also close to M. polymorpha Koelbel, 1892, from Lanzarote, Canary Islands, and M. talismani A. Milne Edwards and Bouvier, 1894, from the NW Africa. The new species is described and illustrated and a diagnosis along with full illustration is provided for the latter 2 species.
\end{abstract}

Keywords: Galatheoidea, morphology, new species, deep-sea.

RESUMEN: Una nueva especie de Crustáceo del Género Munidopsis (Crustacea: Decapoda: Munidopsidae) del Mar Mediterráneo. - Se describe una especie nueva de Munidopsis Whiteaves, 1874 capturada al sur de Creta, a 2046$2104 \mathrm{~m}$, en el Mediterráneo oriental. La especie (M. ariadne) es próxima morfológicamente a M. maunga Schnabel and Bruce, 2006, de Nueva Zelanda. La especie está también relacionada con M, polymorpha Koelbel, 1892, de Lanzarote, Islas Canarias, y M. talismani A. Milne Edwards and Bouvier, 1894, del NO de África. Se describe e ilustra la nueva especie y se incluye una ilustración completa y una diagnosis de estas dos últimas especies.

Palabras clave: Galatheoidea, morfología, especie nueva, mar profundo.

\section{INTRODUCTION}

The Mediterranean Sea is one of the "hot spots" of the world in marine biodiversity (Fredj and Laubier, 1985). Recent reviews have demonstrated the importance of this area, which shows a high level of endemism, mostly influenced by its geological and evolutionary history and oceanographic regime (Danovaro et al., 2010). Although our knowledge of the deep-sea ecosystems and biodiversity of the Mediterranean is thought to be considerable, recent studies based on rarefaction curves suggest that a high proportion of the overall Mediterranean deep-sea fauna is still undiscovered (Danovaro et al., 2010). The proportion of endemic species in the Mediterranean basin is much lower in the deep sea than in shallow water areas (Fredj and Laubier, 1985, Galil and Goren, 1994). However, some interesting endemic deep-sea decapods have been found in this basin: e.g. Zariquieyon inflatus, Chaceon mediterraneus, and Levantocaris hornungae (Manning and Holthuis, 1989, Galil and Clark, 1993).

The genus Munidopsis Whiteaves, 1874 belongs to the family Munidopsidae Ortmann, 1898 (Ahyong et al., 2010) and is one of the most diverse genera of the superfamily Galatheoidea (see Baba et al., 2008). Species of this genus are commonly found living on the continental slope, usually below $500 \mathrm{~m}$, and on the abyssal plain below $2000 \mathrm{~m}$ (Baba, 2005; Macpherson, 2007). The genus Munidopsis is so far represented by more than 70 species in the Atlantic Ocean (Macpherson and Segonzac, 2005, Baba et al., 2008), with a depth distribution ranging from $2 \mathrm{~m}$ (M. polymorpha 
Koelbel, 1892) to 5330 m [M. parfaiti (Filhol, 1885) and M. thieli Türkay, 1975]. In contrast, in the Mediterranean Sea the genus is only represented by 3 smallsized species:

1. Munidopsis acutispina Benedict, 1902 reported from Sardinia, in the western Tyrrenian Sea at 374$1036 \mathrm{~m}$ (Froglia et al., 2002) and the eastern Mediterranean at $2030 \mathrm{~m}$ (Macpherson and Segonzac, 2005). The species is also known from the mid-Atlantic Ridge, at $830 \mathrm{~m}$, and off Mauritania and Morocco at 698-950 m (A. Milne Edwards and Bouvier, 1894, 1899, 1900, Macpherson and Segonzac, 2005), and on the Galicia Bank (Macpherson, unpublished data).

2. Munidopsis marionis (A. Milne Edwards, 1881) is endemic to the Mediterranean Sea. It was first recorded from Planier Island, western Mediterranean, at $450 \mathrm{~m}$ (A. Milne Edwards and Bouvier, 1900). The species was found again in the eastern Mediterranean, at 1000-1700 m (Galil and Goren, 1994, Macpherson and Segonzac, 2005), and Sardinia (western Tyrrhenian Sea) at 374-571 m (Froglia et al., 2002).

3. Munidopsis serricornis (Lovén, 1852) reported from the NW Mediterranean, at 960-1580 m (Abelló and Valladares, 1988, Cartes, 1993, Cartes et al., 1993). The species is known from numerous localities in the Atlantic Ocean, between 92 and $2165 \mathrm{~m}$ (Baba et al., 2008). The occurrences along the Indian and $\mathrm{Pa}-$ cific Oceans are under study and probably belong to a different species. The species has often been reported under the synonymy Munidopsis tridentata.

The very few individuals of the genus Munidopsis collected by numerous cruises carried out in the deep waters of the Mediterranean Sea (Danovaro et al., 2010) suggest that this genus is poorly represented in the area. Low abundances of these animals seem to be supported by the fact that only a single specimen was recovered in the eastern basin, south of the Crete Island, at 2046-2104 m during the cruise BIOFUN. However, this specimen is a new species, being clearly differentiated from the 3 above-listed species. In the present paper this species is described and illustrated. The new species belongs to the group having a narrowly triangular rostrum, a smooth dorsal carapace surface smooth (at most 1 pair of epigastric spines), unarmed abdominal tergites, the chelipeds longer than walking legs, unarmed eyes, and absence of epipods from the pereopods (Baba, 2005). In the NE Atlantic Ocean there are only 2 species of this group: M. polymorpha Koelbel, 1892, from Lanzarote, Canary Islands, and $M$. talismani A. Milne Edwards and Bouvier, 1894, from NW Africa. These 2 species are only partially illustrated in the literature. Therefore, in order to facilitate the comparison among species, the diagnoses and full illustrations of these 2 known species are also provided.

The size of the carapace is indicated as the postorbital carapace length measured along the dorsal midline from the posterior orbital margin to the posterior margin of the carapace. The terminology used mainly follows Baba (2005). The abbreviations used are: P1 = first pereopod (cheliped), P2-4 = second to fourth pereopods (first to third walking legs). The specimens studied are deposited in the Institut de Ciènces del Mar (CSIC), Barcelona (ICM), Muséum national d'Histoire naturelle, Paris (MNHN), and Senckenberg Museum, Frankfurt (SMF).

\section{SYSTEMATIC ACCOUNT}

\section{Munidopsis ariadne n. sp.} (Fig. 1)

Material examined. Eastern Mediterranean (South Crete). BIOFUN, Stn BF1M16, 34'36.77'N, 2552.34'E, 17 June 2009, 2046-2104 m: 1 male $6.0 \mathrm{~mm}$, holotype (ICMD-20110120_01).

Etymology. The name ariadne, in the Greek mythology, refers to the daughter of the king Minos of Crete and his queen, Pasiphaë.

Description. Carapace: 1.4 times longer than broad; dorsal surface moderately convex from side to side, smooth, with some short striae, and few short uniramous setae; unarmed except for paired well-developed epigastric spines. Regions well delineated by furrows including distinct anterior and posterior cervical grooves. Posterior cardiac region weakly triangular, preceded by deep transverse depression. Posterior margin preceded by elevated ridge. Rostrum narrowly triangular, nearly horizontal in lateral view, terminating in acute tip, length 1 quarter that of remaining carapace; dorsal surface with longitudinal ridge; lateral margins carinated and straight. Frontal margin slightly oblique behind ocular peduncle, leading to antennal spine, then convex toward anterolateral corner of carapace. Antennal spine directed straight forward; distinct spine ventral to frontal margin between ocular and antennal peduncles. Lateral margins weakly convex and subparallel; anterolateral spine well developed but smaller than antennal spine; anterior end of anterior branch of cervical groove with distinct notch followed by distinct spine situated at anterior end of branchial margin; anterior end of posterior cervical groove without notch, followed by small spine distantly posterior to it. Pterygostomian flap smooth, with small striae, anteriorly unarmed.

Sternum: Slightly longer than broad, maximum width at sternites 6 and 7. Sternite 3 moderately broad, 3 times wider than long, anterior margin with shallow median notch flanked by 2 low lobes, lateral margin somewhat angular. Sternite 4 narrowly elongate anteriorly; surface depressed in midline, smooth; greatest width twice that of sternite 3, and twice wider than long.

Abdomen: Smooth, unarmed; tergites 2-3 each with 2 elevated transverse ridges, but tergites 4-6 lacking such ridges; tergite 6 with weakly produced posterolateral lobes and nearly transverse posteromedian margin. Telson composed of 10 plates; posterior plates combined 1.8 times as wide as long. 


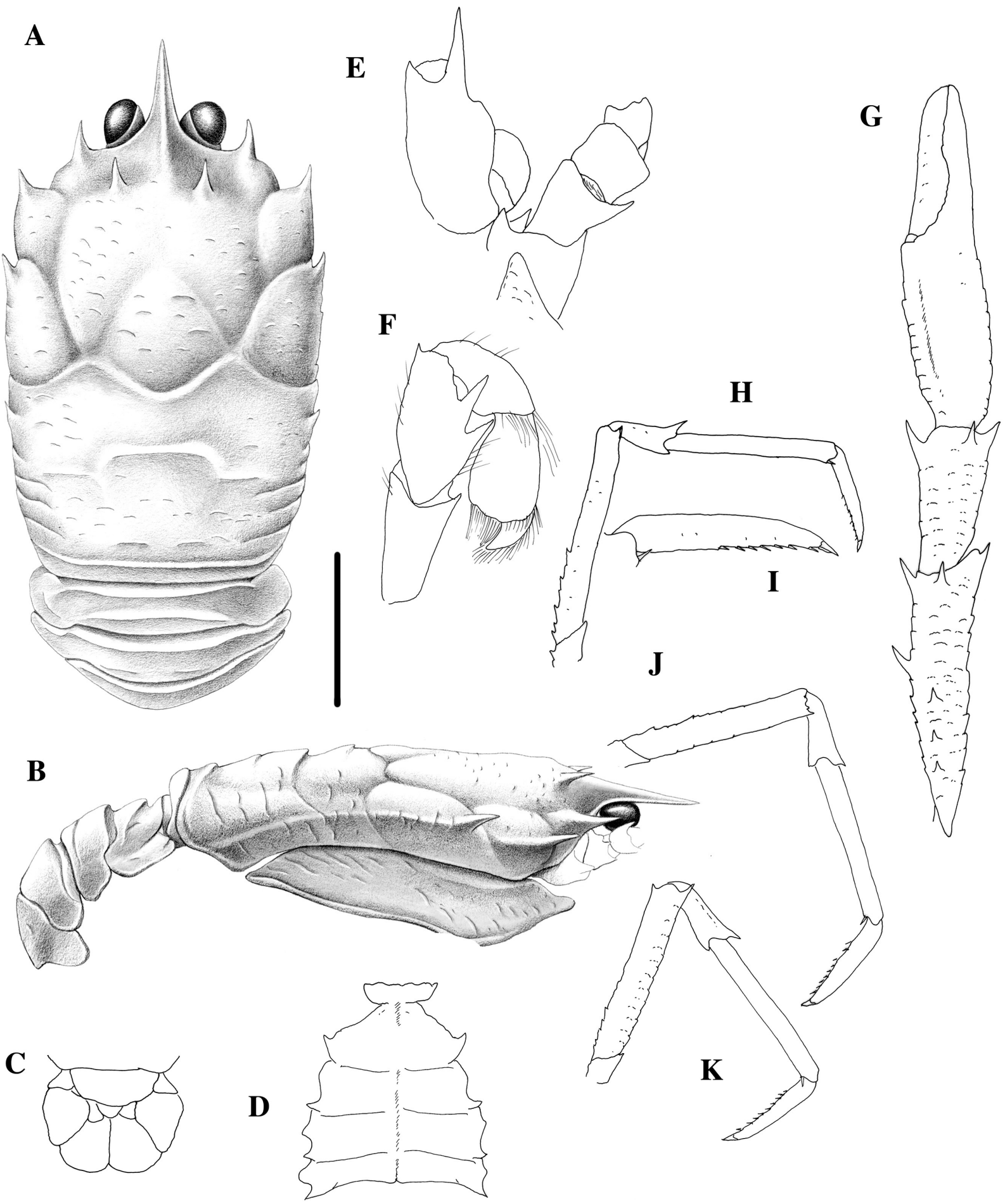

FIG. 1. - Munidopsis ariadne n. sp. Holotype, male 6.0 mm (ICMD-20110120_01). A, carapace and abdomen, dorsal view. B, carapace and abdomen, right lateral view. C, telson. D, sternal plastron. E, left antenna and antennula, ventral view. F, right maxilliped 3. G, right P1. H, Right P2. I, Right P2 dactylus. J, Right P3. K, Right P4. Scale: A-D, 2.0 mm; G, H, J, K, 1 m; E-F, I, 0.5 mm.

Eye: Ocular peduncle immobile. Cornea subglobular, non-pigmented, unarmed, as wide as eyestalk.

Antennule: Basal article of antennular peduncle with strong distolateral spine, distomesial spine small; lateral margin swollen, with minute tubercle.
Antenna: Antennal peduncle reaching end of rostrum; article 1 with distomesial and distolateral spines, both short, not reaching mid-length of article 2; article 2 armed with short distolateral spine, unarmed on distomesial angle; articles 3 and 4 unarmed. 
Maxilliped 3: Ischium as long as merus measured on extensor margin; flexor margin sharply ridged, terminating in small spine; extensor margin unarmed; 20 corneous denticles on crista dentata; merus having flexor margin with 2 distinct subequal spines, extensor margin with small distal spine; carpus, propodus and dactylus unarmed.

Pereopod 1 (cheliped): Left and right appendages subequal, 3 times longer than carapace, with short striae and some small granules; uniramous setae scattered on merus to dactylus. Merus with 3 distal spines (lateral, mesial, and dorsal) and row of mesial and dorsal spines. Carpus twice longer than high, with 3 distal spines (lateral, mesial and dorsal). Palm slender, nearly 1.3 length of carpus, 2.3 times as long as high, and 1.2 times as long as fingers. Fingers not gaping; prehensile edges each with row of subtriangular teeth, proximal teeth obsolete; fixed finger without denticulate carina on distolateral margin.

Pereopods 2-4 (walking legs): moderately slender, with few small granules and short striae on dorsal surface, somewhat compressed laterally, P2 slightly longer than P3 and P4, overreaching end of $\mathrm{P} 1$ carpus; ischium to propodus with few uniramous setae; dactylus with tufts of short simple setae. P2 merus elongate, slightly shorter than carapace, 3.5 times length of P2 carpus and 1.4 times length of $\mathrm{P} 2$ propodus, 1.1 times length of $\mathrm{P} 4$ merus. P2-4 meri with distal spine on dorsal and ventral margin; carpi with prominent, blunt distal spine, lateral side with longitudinal crest; propodi 7.4 times as long as high, unarmed except for 2 corneous distal spines on ventral margin; dactyli 0.7 length of propodi; distal claw short, moderately curved; flexor margin nearly straight, with 8 (on P2) or 9 (on P3-4) small teeth decreasing in size proximally, each with slender corneous spine, ultimate tooth equidistant between dactylar tip and penultimate tooth. Epipods absent from P1-4.

Colour: whitish.

Remarks. Munidopsis ariadne belongs to the group of species with the carapace unarmed (except pair of epigastric spines), abdomen smooth, rostrum short and narrowly triangular, P1 longer than P2, eye with immobile ocular peduncle, and cornea subglobular and unarmed. The closest species is M. maunga Schnabel and Bruce, 2006, from the caldera of Macauley volcano within the Kermadec volcanic arc (north of New Zealand), at 636-751 m (Schnabel and Bruce, 2006). Munidopsis ariadne is also closely related to M. polymorpha from a shallow anchialine system in Lanzarote, Canary Islands (Figs. 2-3) and M. talismani from the NW Africa (between 830-1113 m) (Fig. 4).

Munidopsis ariadne is distinguished from M. maun$g a$ by the following: the rostrum is dorsally carinated instead of smooth; the P2 merus is slightly shorter than instead of half as long as the carapace; and the epigastric spines are clearly larger.

Munidopsis ariadne can be easily distinguished from $M$. polymorpha by the shape of the rostrum and
$\mathbf{A}$

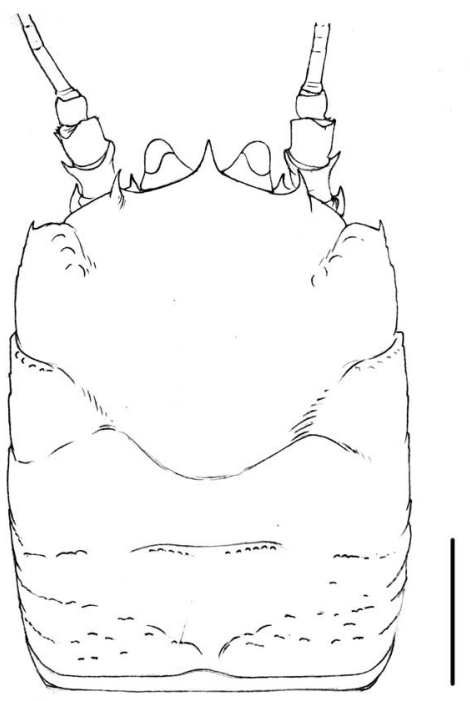

B

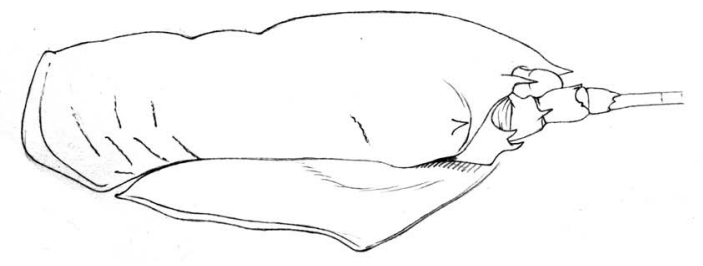

FIG. 2. - Munidopsis polymorpha Koelbel, 1892, male $7.2 \mathrm{~mm}$ (MNHN-Ga185), carapace. A, dorsal view. B, lateral view. Scale: $3.5 \mathrm{~mm}$.

the spinulation of the carapace. In M. polymorpha the rostrum is clearly shorter and not carinated, and the carapace is unarmed, without epigastric and lateral spines, whereas in the new species the rostrum is narrowly triangular, and the carapace is armed with epigastric and lateral spines.

Munidopis ariadne differs from M. talismani in the following features: the carapace bears 2 epigastric, 1 antennal and 1 laterobranchial spine, instead of being unarmed; the rostrum is horizontal and dorsally carinated rather than being directed upwards, without dorsal carina; the flexor margin of the P2-4 dactyli are nearly straight instead of distinctly concave; and the ultimate of the flexor teeth is closer to rather than remote from the dactylar tip.

Distribution. Known only from the Mediterranean Sea, south of Crete, at 2046-2104 m.

Munidopsis polymorpha Koelbel, 1892 (Figs. 2-3)

Munidopsis polymorpha Koelbel, 1892: 109, pl. 10, Figs. 3-16. Baba et al., 2008: 155 (compilation).

Material examined. Canary Islands. Lanzarote. Jameos del Agua cave, 2-8 m. 16.12.1933, L. Fage and Th. Monod coll.: 18 males 6.0-9.0 mm, 6 ovigerous females 7.0-9.0 mm, 9 females 4.0-6.8 mm (MNHN-Ga185). - 05.02.1971, Rubio leg.: 1 male $6.2 \mathrm{~mm}$ (MNHN-Ga 289). — 30.12.1997: 2 males 6.1-6.5 mm (ICM). 

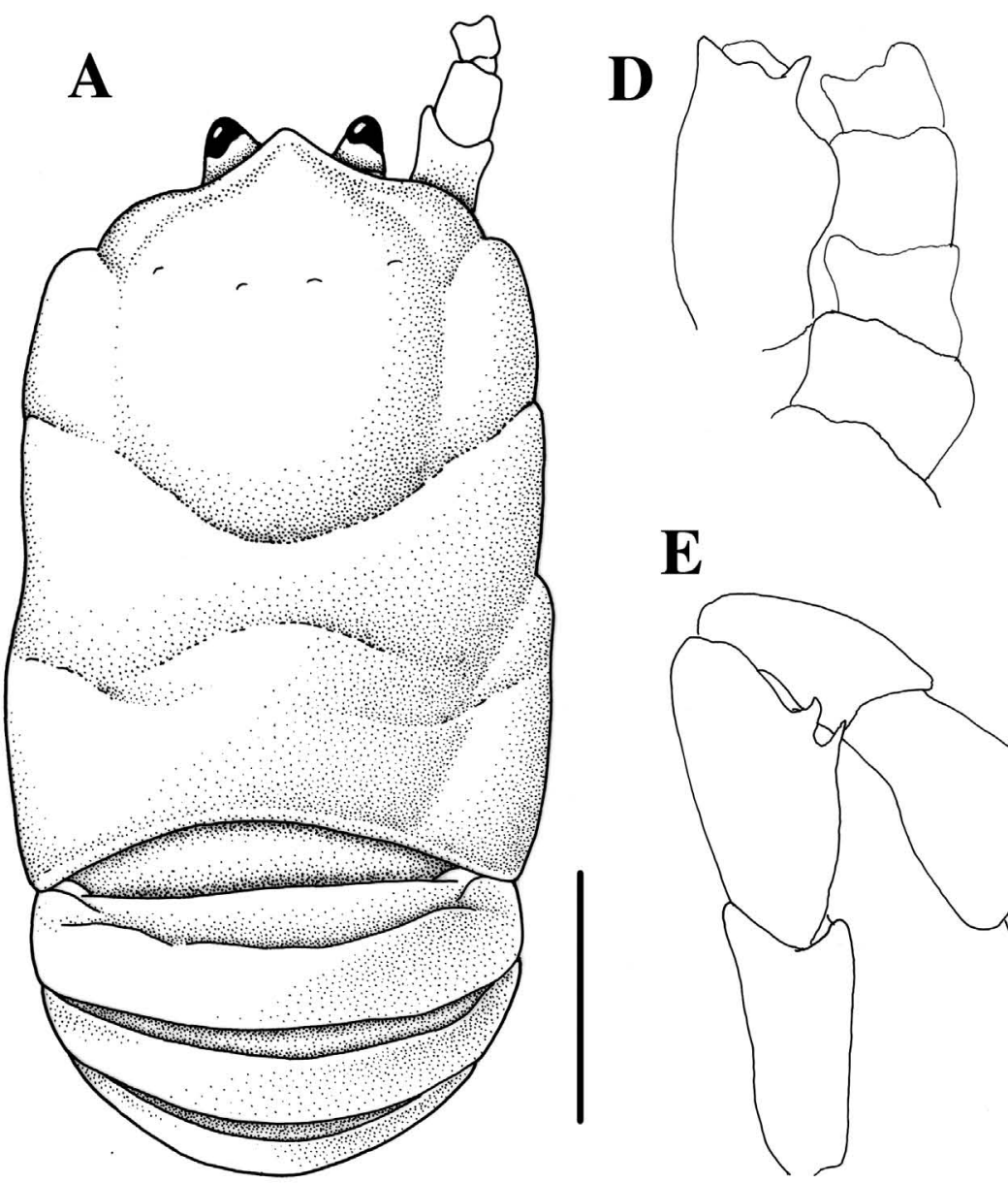

$\mathbf{E}$
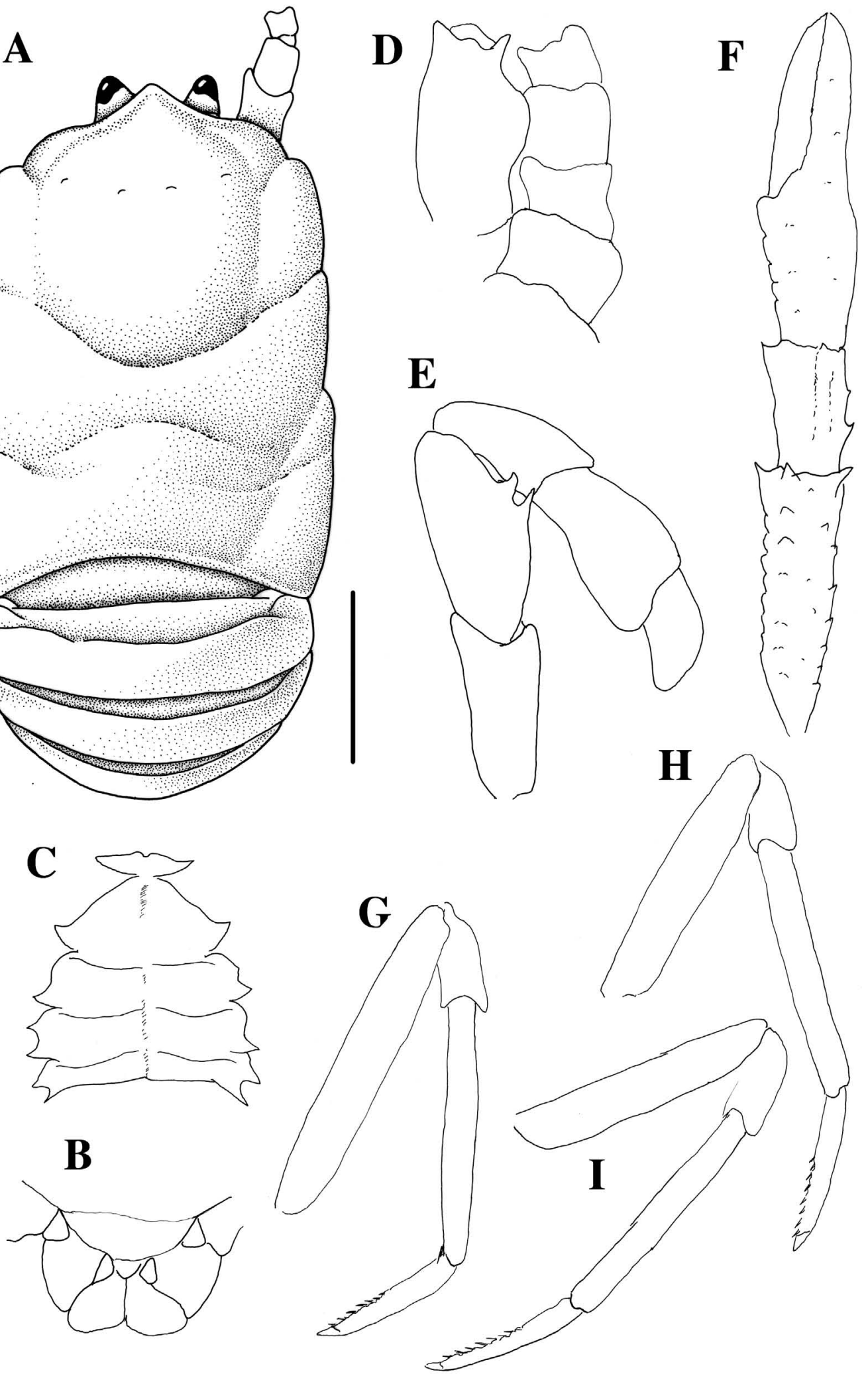

FIG. 3. - Munidopsis polymorpha Koelbel, 1892, male $6.1 \mathrm{~mm}$ (ICM). A, carapace and abdomen, dorsal view. B, telson. C, sternal plastron. D, left antenna and antennula, ventral view. E, right maxilliped 3. F, right P1. G, Right P2. H, Right P3. I, Right P4. Scale: A-C, F-I, 2.0 mm; D-E, $1.0 \mathrm{~mm}$. 


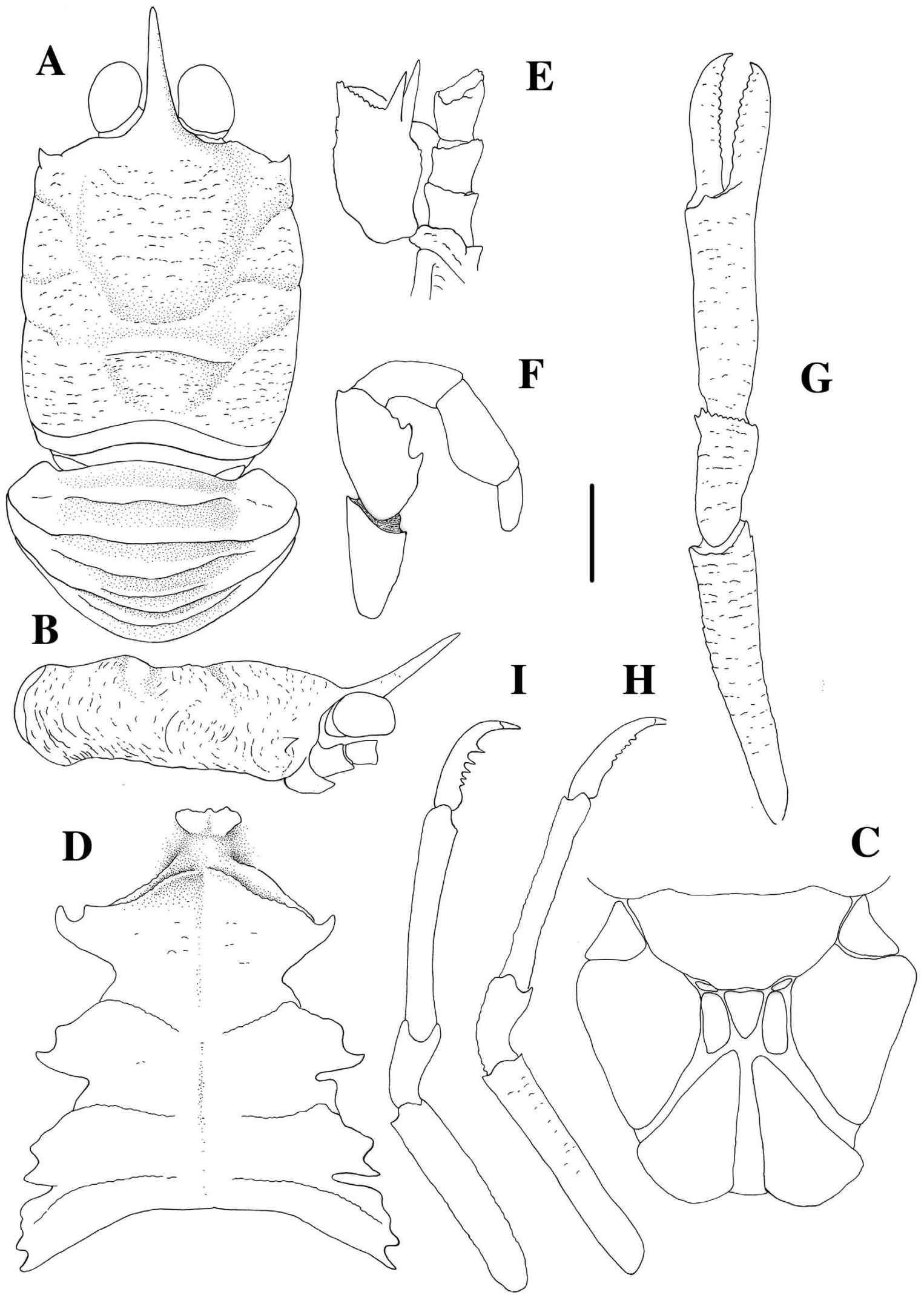

Fig. 4. - Munidopsis talismani A. Milne Edwards and Bouvier, 1894, female $7.0 \mathrm{~mm}$ (SM). A, carapace and abdomen, dorsal view. B, carapace, right lateral view. C, telson. D, sternal plastron. E, left antenna and antennula, ventral view. F, right maxilliped 3. G, right P1. H, Right P2. I, Right P4. Scale: A-B, $3.0 \mathrm{~mm} ;$, G-I, $2.0 \mathrm{~mm}$; C-F, $1.0 \mathrm{~mm}$. 
Diagnosis. Carapace smooth, unarmed. Anterolateral angle of carapace rounded, lateral margins unarmed. Rostrum very short, spiniform, sometimes reduced to blunty produced process, nearly horizontal, dorsally smooth. No spines on abdominal tergites; tergite 6 with weakly produced posterolateral lobes and nearly transverse posteromedian margin. Telson composed of 10 plates; posterior plates combined 2.1 times as wide as long. Cornea subglobular, nonpigmented, shorter than remaining peduncle; eyespine absent. P1 less than 3 times carapace length; fixed finger without denticulate carina on distolateral margin. P2 not reaching end of P1. P2-4 propodi of uniform width, more than 3 times longer than high; dactyli having flexor margin nearly straight, with distinct serration. Epipods absent from P1-4.

Remarks. This species is collected in the lava tubes of Lanzarote. These tubes were formed by eruptions of the volcano Monte Corona during the Holocene. There are some studies on its occurrence and population biology (Wilkens et al., 1990 and references cited therein). Koelbel (1892) described the species based on numerous specimens collected in the tube Jameos del Agua, emphasizing the variability of the rostrum shape (see Figs. 2A and 3A). Calman (1904) also mentioned this variability.

Distribution. Lanzarote (Canary Islands), at 2-8 m.

Munidopsis talismani A. Milne Edwards and Bouvier, 1894 (Fig. 4)

Munidopsis Talismani A. Milne Edwards and Bouvier, 1894: 198, 230, 275. A. Milne Edwards and Bouvier, 1900: 316, pl. 30, Figs. 10-14. Baba et al., 2008: 168 (compilation).

Material examined. NW Africa. Cape Barbas. $22^{\circ} 52^{\prime} \mathrm{N}, 19^{\circ} 43^{\prime} \mathrm{W}$, $830-850 \mathrm{~m}, 12$ July $1883: 1$ male $6.1 \mathrm{~mm}, 3$ ovigerous females 5.5$7.8 \mathrm{~mm}$, syntypes (MNHN-Ga293, 294, 295).

NW Africa. Ras-al-Abiad Cape. FS Meteor. Cruise Auftrieb 75. Stn M36-103AT154. 21ํ24.6'N, 1753.6'W, 27 February 1975, 1023$1040 \mathrm{~m}$ : 2 males $5.3-5.6 \mathrm{~mm}, 4$ ovigerous females $5.8-7.2 \mathrm{~mm}, 1$ female $7.0 \mathrm{~mm}$ (SMF).

Diagnosis. Dorsal surface of carapace smooth, without epigastric spines; antennal spine absent, anterolateral angle with short spine, lateral margins unarmed. Rostrum narrowly triangular, not dorsally carinated, strongly upcurved. Anterior end of branchial lateral margin unarmed. No spines on abdominal tergites; tergite 6 with weakly produced posterolateral lobes and nearly transverse posteromedian margin. Telson composed of 12 plates; posterior plates combined 1.5 times as wide as long. Cornea semi-oval, not pigmented, longer than remaining eyestalk; eyespine absent. P1 less than 3 times carapace length; fixed finger without denticulate carina on distolateral margin. P2 not reaching end of P1. P2-4 propodi of uniform width; dactyli having flexor margin curved, with distinct serration, ultimate tooth much more remote from dactylar tip than from penultimate tooth. Epipods absent from pereopods.

Remarks. This species was described from the material collected by the Talisman in 1883 . The description by A. Milne Edwards and Bouvier $(1894,1900)$ is well detailed. However, the illustration of the carapace has several errors. For instance, the rostrum is dorsally carinated and the anterolateral spines are strong in the 1900s figure. Examination of the type material and additional specimens shows that the rostrum is dorsally convex, and the anterolateral spines are distinct but not strong.

Distribution. The species was only known from the type localities (Cape Barbas and Arguin Bank). The collection site made by the R/V Meteor is situated slightly north of the type localities. The species occurred between 830 and $1040 \mathrm{~m}$.

\section{ACKNOWLEDGEMENTS}

I am indebted to Joan Baptista Company and Francesc Sarda (ICM, Barcelona, Spain) for providing me with the specimen of the new species used in this study. Keiji Baba (Kumamoto University, Japan), K. Schnabel (NIWA, New Zealand), and P. Cabezas (Museo Nacional de Ciencias Naturales, Madrid, Spain) kindly reviewed and improved the manuscript. I also thank the following colleagues who made specimens available for study: A. Crosnier, R. Cleva and the late M. de Saint Laurent (MNHN, Paris, France), and M. Türkay (Senckenberg Museum, Frankfurt, Germany). The species were illustrated by J. Macpherson. This is a contribution of the BIOFUN project.

\section{REFERENCES}

Abelló, P. and F.J. Valladares. - 1988. Bathyal decapod crustaceans of the Catalan Sea (Northwestern Mediterranean). Mésogée, 48: 97-102.

Ahyong, S.T., K. Baba, E. Macpherson and G.C.B Poore. - 2010. A new classification of the Galatheoidea (Crustacea: Decapoda: Anomura). Zootaxa, 2676: 57-68.

Baba, K. - 2005. Deep-sea chirostylid and galatheid crustaceans (Decapoda: Anomura) from the Indo-West Pacific, with a list of species. Galathea Rep., 20: 1-317.

Baba K., E, Macpherson, G.C.B Poore, S. T. Ahyong, A. Bermudez, P. Cabezas, C.W. Lin, M. Nizinski, C. Rodrigues and K.E. Schnabel. - 2008. Catalogue of squat lobsters of the world (Crustacea: Decapoda: Anomura - families Chirostylidae, Galatheidae and Kiwaidae). Zootaxa, 1905: 1-220.

Benedict, J.E. - 1902. Description of a new genus and forty six new species of crustaceans of the family Galatheidae with a list of the known marine species. Proc. Biol. Soc. Wash., 26: 243-334.

Calman, W.T. - 1904. On Munidopsis polymorpha Koelbel, a cavedwelling marine crustacean from the Canary Islands. Ann. Mag. Nat. Hist. (ser. 7), 14: 213-218.

Cartes, J.E. - 1993. Deep-sea decapod fauna of the western Mediterranean: bathymetric distribution and biogeographic aspects. Crustaceana, 65: 29-40.

Cartes, J.E., F. Sardá and P. Abelló. - 1993. Decapod crustaceans collected by deep-water trawls (between 1000 and $2200 \mathrm{~m}$ ) in the Catalan area (North-western Mediterranean). Bios (Thessaloniki), 1: 207-213. 
Danovaro, R., J. B. Company, C. Corinaldesi, G. D’Onghia, B. Galil, C. Gambi, A. J. Gooday, N. Lampadariou, G. M. Luna, C. Morigi, K. Olu, P. Polymenakou, E. Ramirez-Llodra, A. Sabbatini, M. Sibuet and A. Tselpides. - 2010. Deep-Sea Biodiversity in the Mediterranean Sea: The Known, the Unknown, and the Unknowable. Plos One, 5(8): e0011842.

Filhol, H. - 1885. La vie au fond des mers. Les explorations sousmarines et les voyages du Travailleur et du Talisman. Masson, Paris.Fredj, G. and L. Laubier. - 1985. The deep Mediterranean benthos. In: M. Moraitou-Apostolopoulou and V. Kiortsis (eds.), Mediterranean Marine Ecosystems, pp. 109-145. Plenum Press, New York and London.

Froglia, C., M. Mura and A. Bonfitto. - 2002. First record of Munidopsis acutispina Benedict, 1902 (Decapoda, Anomura, Galatheidae) in the Mediterranean Sea. Crustaceana, 75: 375-382.

Galil, B.S. and P.F. Clark. - 1993. A new genus and species of Axiid (Decapoda, Thalassinidae) from the Levantine basin of the Mediterranean. Crustaceana, 64: 48-55.

Galil, B.S. and M. Goren. - 1994. The deep sea Levantine fauna. New records and rare occurrences. Sencken. Marit., 25: 41-52.

Koelbel, C. - 1892. Beitraege zur Kenntnis der Crustaceen der Canarischen Inseln. Ann. Natur. Mus. Wien, 7: 105-116.

Lovén, S. - 1852. De svenska arterna af slägtet Galathea. Ofv. Kongl. Vet.-Akad. Förh., 9: 20-23.

Macpherson, E. - 2007. Species of the genus Munidopsis Whiteaves, 1784 from the Indian and Pacific Oceans and reestablishment of the genus Galacantha A. Milne-Edwards, 1880 (Crustacea, Decapoda, Galatheidae). Zootaxa, 1417: 1-135.

Macpherson, E. and M. Segonzac. - 2005. Species of the genus Munidopsis (Crustacea, Decapoda, Galatheidae) from the deep Atlantic Ocean, including cold-seep and hydrothermal vent areas. Zootaxa, 1095: 1-60.

Manning, R.B. and L.B. Holthuis. - 1989. Two new genera and nine new species of Geryonid crabs (Crustacea, Decapoda, Geryonidae). Proc. Biol. Soc. Wash., 102: 50-77.

Milne Edwards, A. - 1881. La campagne de dragages du "Travail- leur" dans la Méditerranée et dans l'Atlantique, en 1881. La Nature, Paris, 447: 50-56.

Milne Edwards, A. and E. L. Bouvier. - 1894. Considerations génerales sur la famille des Galatheides. Ann. Sci. Natur. Zool. (ser. 7), 16: 191-327.

Milne Edwards, A. and E.L. Bouvier. - 1899. Crustacés décapodes provenant des campagnes de l'Hirondelle (supplément) et de la Princesse-Alice (1891-1897). Rés. Camp. Scient. Yacht Albert Ier Prin. Monaco, 13: 1-106.

Milne Edwards, A. and E.L. Bouvier. - 1900. Crustacés décapodes. Première partie. Brachyures et Anomoures. In: A. Milne-Edwards (ed.), Expéditions scientifiques du Travailleur et du Talisman pendant les années 1880, 1881, 1882, 1883. Masson, Paris.

Ortmann, A.E. - 1898. Crustacea, Malacostraca. In: Gerstäcker,A. aOrtmann A.E. (eds.), Die Klassen und Ordnungen der Arthropoden wissenschaftlich dargestellt in Wort und Bild, in H.G. Bronn's Die Klassen und Ordnungen der Thier-Reichs wissenschaftlich dargestellt in Wort und Bild, 5(2): 1057-1168, pls. 109-116. C.F. Winter'sche Verlagshandlung, Leipzig.

Schnabel, K.E. and N.L. Bruce. - 2006. New records of Munidopsis (Crustacea : Anomura : Galatheidae) from New Zealand with description of two new species from a seamount and underwater canyon. Zootaxa, 1172: 49-67.

Türkay, M. - 1975. Decapoda Reptantia aus den Iberischen Tiefseebecken Auswertung der Fahrten 3 (1966) und 15 (1968) von F.S. "Meteor". "Meteor" Fors.-Ergeb. Reihe D, 20: 66-70.

Whiteaves, J.F. - 1874. On recent deep-sea dredging operations in the Gulf of St. Lawrence. Amer. Journ. Sci. (ser. 3), 7: 210-219.

Wilkens, H., J. Parzefall and A. Ribowski. - 1990. Population biology and larvae of the anchialine crab Munidopsis polymorpha (Galatheidae) from Lanzarote (Canary Islands). J. Crustac. Biol., 10: 667-675.

Scient. ed.: P. Abelló.

Received December 3, 2010. Accepted January 21, 2011.

Published online April 27, 2011. 